\title{
O Projeto de Norma da Corte de Justiça do Mercosul e o (DES)Amparo aos Direitos Humanos
}

\author{
The Draft Standard of the Mercosur Court of Justice \\ AND THE SUPPORT (OR NOT) FOR HUMAN RIGHTS
}

Juliane Caravieri Martins Gamba(*)

"Para além de suas diferentes atitudes - otimistas ou pessimistas, realistas ou idealistas - os juristas precisam assumir, portanto, as responsabilidades ligadas à sua profissão. E, se é verdade que a curto prazo não podemos nos iludir, é também verdade que a história nos ensina que os direitos não caem do céu, e um sistema de garantias efetivas não nasce numa prancheta, não se constrói em poucos anos, nem tampouco em algumas décadas. Assim foi com o Estado de direito e com nossas democracias ainda frágeis, que só se afirmam à custa de longas batalhas no campo das idéias e de lutas sangrentas. Seria irracional pensar que o mesmo não acontecerá com o direito internacional e não nos empenharmos na parte que nos cabe."

Luigi Ferrajoli

Resumo: Em face da existência de normas internacionais de proteção aos direitos humanos, de cunho global e regional, e de ordenamentos constitucionais que objetivam a valorização da dignidade da pessoa humana, mostra-se - como imperativo para a coexistência entre os povos e a manutenção da paz na atualidade - a implementação de controles jurisdicionais do Estado mediante a criação de tribunais supranacionais, sobretudo no âmbito dos processos de integração regional. Nesse contexto, em dezembro de 2010, foi aprovado pelo Parlamento do MERCOSUL (PARLASUL) um projeto de norma para a criação da Corte de Justiça - em substituição ao Protocolo de Olivos (2002) utilizado na solução de controvérsias - como órgão jurisdicional, judicial e independente para garantir a aplicação e a interpretação uniforme das normas no bloco, sendo necessário seu estudo ainda em caráter preliminar. O artigo estudou o texto legal deste projeto com ênfase nos seguintes aspectos: descrição e análise dos instrumentos jurídico-processuais que poderão ser impetrados por pessoas físicas e jurídicas perante esse órgão jurisdicional, tais como: ações de nulidade; ações por omissão; ações de descumprimento ou violação; ações por questão predominante/prejudicial; e, ainda, análise

(*) Doutoranda em Integração da América Latina pela Universidade de São Paulo (USP). E-mail: <jcaravieri@usp.br>. Recebido em 14.03.12 e aceito em 20.05.12. 
dos limites e deficiências da competência ratione materiae. Porém, esse projeto propõe a criação de uma Corte de Justiça permanente que não resolverá todas as espécies de litígios que poderão se constituir no bloco, principalmente aqueles que envolvam as relações de trabalho e as demandas no âmbito penal. Portanto, resta saber como se efetivará o controle jurisdicional e a solução de controvérsias entre os Estados-partes, pessoas físicas e pessoas jurídicas na Corte de Justiça do MERCOSUL, principalmente no caso da tutela dos direitos humanos. É necessária a implementação de tribunais supranacionais para a garantia da democracia e do respeito aos direitos da pessoa humana no âmbito dos processos de integração regional.

Palavras-chave: Direitos humanos; integração; jurisdição internacional; MERCOSUL.

Abstract: Given the existence of international human rights protection, on a global and regional, and constitutional provisions that aim to promote the dignity of the human person, it is shown - as an imperative for coexistence among peoples and peace-keeping nowadays the implementation of jurisdictional control of the state through the creation of supranational courts, especially in the context of regional integration processes. In this context, in December 2010, was approved by the Parliament of MERCOSUR (Parlasur) a draft standard for the creation of the Court of Justice - to replace the Protocol of Olivos (2002) used in settlement of disputes - also as court, judicial and independently to ensure the uniform application and interpretation of standards in the block, requiring that its study on a preliminary. The article studied the legal text of this project with emphasis on: description and analysis of legal and procedural tools that may be filed by individuals and corporations before that court, such as actions of nullity; default actions; actions of noncompliance or violation, issue shares for dominant / ruling and also analysis of the limitations and deficiencies of competence ratione materiae. However, this project proposes the creation of a permanent Court of Justice will not solve all kinds of disputes that may constitute the block, especially those involving labor relations and the demands on the criminal law. So the question is how to become effective jurisdictional control and settlement of disputes between states, individuals and corporates of MERCOSUR Court of Justice, especially concerning the protection of human rights. Is necessary to implement supranational courts to guarantee democracy and respect for human rights from in the context of regional integration processes.

Keywords: Human rights; integration; international jurisdiction; MERCOSUR. 


\section{INTRODUÇÃo}

Após a Segunda Guerra Mundial, houve a consolidação na ordem internacional de blocos econômicos de integração regional que objetivaram o fortalecimento econômico e político dos Estados-partes no intuito de obter maior competitividade no comércio mundial. Na América Latina, apesar de haver outras propostas de integração regional, destacou-se o Mercado Comum do Sul (MERCOSUL) criado, em 1991, mediante a assinatura do Tratado de Assunção entre Brasil, Argentina, Paraguai e Uruguai.

O MERCOSUL assumiu mais uma feição de aliança comercial com vistas a dinamizar a economia regional e, inicialmente, não houve preocupação com questões sociais, culturais, identitárias e nem com a tutela jurídica dos direitos da pessoa humana nos tratados que fundamentaram a criação e a institucionalização do bloco. Entretanto, na atualidade, em face da existência de normas internacionais de proteção aos direitos humanos, de cunho global e regional, e de ordenamentos constitucionais que objetivam a valorização da dignidade da pessoa humana, é necessário criar controles jurisdicionais por intermédio de tribunais supranacionais no âmbito de processos de integração regional.

Em dezembro de 2010, foi aprovado pelo Parlamento do MERCOSUL (PARLASUL) o Projeto de Norma "MERCOSUR/PM/PN 02/2010" para a criação da Corte de Justiça — em substituição ao Protocolo de Olivos (2002) utilizado atualmente na solução de controvérsias - como órgão jurisdicional, judicial e independente para garantir a aplicação e a interpretação uniforme das normas no bloco.

Este projeto possui uma parte introdutória que contém "Exposición de Motivos", "Oportunidad", "De la Creación y Organización de la Corte de Justicia", "De las Competencias de la Corte de Justicia", "De las Sentenças y Decisiones", "De la Jurisdicción" e "Conclusión" que justifica a proposta de criação da Corte de Justiça no MERCOSUL. Posteriormente, há cinco capítulos que estabelecem a estrutura da Corte, o perfil dos juízes, a jurisdição, as competências, as ações judiciais cabíveis dentre outros institutos jurídicos, conforme a estrutura a seguir: Capítulo I - "DE LA CREACIÓN Y ORGANIZACIÓN DE LA CORTE DE JUSTICIA" subdivido em Sección I - De la Corte de Justicia; Sección II - Integración e Independencia; Sección III — Requisitos, elección, duración en el cargo, remoción y funcionamento; Sección IV - Inmunidades e Estatuto y reglamento interno; Sección V - El Secretario y el personal e Sección VI Informes y presupuesto; Capítulo I-A - "DE LAS COMPETENCIAS DE LA CORTE DE JUSTICIA" subdivido em Sección I - De la acción de nulidad; Sección II - De la acción por omisión; Sección III - De la acción de incumplimiento; Sección IV - De la cuestión prejudicial; Sección V-De la función arbitral; e Sección VI - De la jurisdicción laboral; Capítulo II - "DE LAS SENTENCIAS Y DECISIONES"; Capítulo III - "DE LA JURISDICCIÓN"; Capítulo IV - "DISPOSIONES GENERALES"; Capítulo VI - "DISPOSIONES TRANSITORIAS" e os FUNDAMENTOS que finalizam a proposta do projeto.

Na Exposição de Motivos do projeto, há a justificação das causas ensejadoras da proposta e das perspectivas para a constituição da Corte de Justiça no MERCOSUL, destacando-se as seguintes assertivas: 
El presente proyecto de Protocolo Constitutivo es el instrumento que da origen a la Corte de Justicia del MERCOSUR [...] como órgano jurisdiccional, judicial, independiente, cuya función esencial será garantizar la interpretación y aplicación uniformes del derecho del MERCOSUR, afianzando la consolidación jurídica e institucional del proceso de integración.

Esta propuesta se basa en la experiencia desarrollada en la aplicación práctica del Protocolo de Brasilia y del Protocolo de Olivos, así como también de los regímenes que pueden encontrarse en el Derecho comunitario comparado (Comunidades Europeas, Comunidad Andina y Sistema de la Integración Centroamericana, entre otros). [...]

La doctrina y la práctica ratifican que la existencia de una Corte de Justicia resulta imprescindible a los fines de consolidar el mecanismo jurídico interno del bloque, lo cual resulta necesario para dotar de seguridad y certeza jurídicas al proceso de integración, y con ello garantizar la aplicación de los derechos que se atribuyen a los Estados Partes, a los órganos regionales y a las personas físicas y jurídicas. Esta conclusión no es ajena al MERCOSUR, sino más bien resume su esencia.

En definitiva, la creación de la Corte de Justicia salvaguardará el Estado de Derecho en el MERCOSUR, elevando su nivel de desarrollo institucional y jurídico, y colmando con ello la ausencia de una instancia jurisdiccional comunitaria. (MERCOSUL, 2011d, p. 01-02 e p. 06-07.)

Então, o Projeto de Norma da Corte de Justiça do MERCOSUL propõe vários institutos jurídicos, órgãos e instituições a serem construídas, criadas e instrumentalizadas no bloco para o avanço da consolidação jurídica e institucional do processo de integração mercosulista.

Ante essa gama variada de questões que poderiam ser analisadas, o presente artigo - para fins didáticos e de método - realizou o estudo do texto legal deste projeto com ênfase nos seguintes aspectos específicos: descrição e análise dos instrumentos jurídico-processuais que poderão ser impetrados por pessoas físicas e jurídicas perante esse órgão jurisdicional, tais como: ações de nulidade; ações por omissão; ações de descumprimento ou violação; ações por questão predominante/prejudicial; e, ainda, análise dos limites e deficiências da competência em razão da matéria (ratione materiae) desta futura Corte, sobretudo em relação às lides trabalhistas, penais e aos direitos humanos de um modo geral.

Apesar de o MERCOSUL ter sido constituído para promover tão somente acordos de cunho comercial e, talvez, aprofundar uma possível integração econômica, na atualidade, se mostra imprescindível a necessidade de elevar o nível institucional do bloco mediante a criação de instituições de caráter supranacional — o primeiro passo já foi dado com a criação do PARLASUL - para que se consolide um Estado Democrático de Direito com o resguardo da democracia e da tutela dos direitos das pessoas e dos povos mercosulistas, havendo o estreitamento do vínculo de solidariedade e de cooperação entre os Estados integrantes do bloco. Esses objetivos também estão presentes nos "Fundamentos" do projeto de norma, in verbis:

Modernamente no puede negarse que la consolidación del Estado de Derecho, la salvaguarda de los derechos fundamentales de las personas y la garantía de los principios democráticos exigen, 
como uno de sus elementos esenciales, la creación de instituciones sólidas, entre las cuales se destacan, por su función, los tribunales de justicia.

En precisamente en este marco en el que se inscribe el presente proyecto de norma, al materializar una propuesta de creación de una Corte de Justicia para nuestro proceso de integración. El proyecto es tributario, sin dudas, de varios actos e iniciativas adoptadas en el ámbito de este Parlamento tendientes al mismo objetivo.

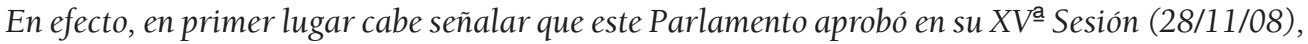

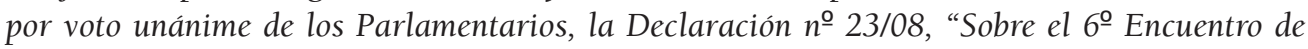
Cortes Supremas", encuentro que tuvo lugar en Brasilia, el 21/11/08. [...] la declaración destaca "que resulta de fundamental importancia para el desarrollo del MERCOSUR y para nuestra integración definitiva la implantación de un único Superior Tribunal de Justicia del MERCOSUR que dirima conflictos e interprete el derecho comunitario, sin perjuicio de la lógica autonomía de los Órganos Judiciales de los Estados Parte" y "que la única manera de posibilitar a los habitantes de nuestro MERCOSUR un mejor nivel o calidad de vida, será cimentándolo sobre la base de la seguridad jurídica, que deberá ser única y no podrá estar sujeta a las distintas interpretaciones de los Órganos judiciales de cada Estado Parte". (MERCOSUL, 2011d, p. 27-28.)

Portanto, é necessária a implementação de controles jurisdicionais do Estado, por intermédio de tribunais supranacionais, para a garantia da democracia e do respeito aos direitos da pessoa humana no âmbito dos processos de integração regional, principalmente no caso do MERCOSUL que envolve povos com diferentes identidades culturais, sociais e históricas.

Assim, é imperioso o estudo deste Projeto de Norma da Corte de Justiça do MERCOSUL, ainda em fase preliminar de votação no PARLASUL, no intuito de contribuir para o aperfeiçoamento das discussões sobre essa temática que, certamente, irão se aprofundar nos próximos anos em face da necessidade de maior institucionalização do bloco.

\section{MERCOSUl, Integração Regional e Direitos Humanos}

Na doutrina constitucionalista contemporânea, tanto nacional quanto estrangeira, há a discussão se "Direitos do Homem", "Direitos Humanos" e "Direitos Fundamentais" seriam consideradas expressões que designassem a mesma categoria jurídica ou se haveria uma diferenciação terminológica ou de conteúdo, sendo notório que se trata de direitos embasados na dignidade da pessoa humana e, consequentemente, inerentes à própria condição humana.

De acordo com Luño (2007, p. 46-47), os direitos humanos podem ser definidos como "un conjunto de facultades e instituciones que, en cada momento histórico, concretan las exigencias de la dignidad, la libertad y la igualdad humanas, las cuales deben ser reconocidas positivamente por los ordenamientos jurídicos a nivel nacional e internacional".

Sarlet (2008, p. 36; p. 38-39) dispõe sobre a distinção entre direitos humanos, direitos do homem e direitos fundamentais:

[...] cumpre traçar uma distinção, ainda que de cunho predominantemente didático, entre as expressões "direitos do homem" (no sentido de direitos naturais não, ou ainda não po- 
sitivados), "direitos humanos" (positivados na esfera do direito internacional) e "direitos fundamentais" (direitos reconhecidos ou outorgados e protegidos pelo direito constitucional interno de cada Estado). [...] as expressões "direitos fundamentais" e "direitos humanos" (ou similares), em que pese sua habitual utilização como sinônimas, se reportam a significados distintos. No mínimo, para os que preferem o termo "direitos humanos", há que referir - sob pena de correr-se o risco de gerar uma série de equívocos - se eles estão sendo analisados pelo prisma do direito internacional ou na sua dimensão constitucional positiva. Reconhecer a diferença, contudo, não significa desconsiderar a íntima relação entre os direitos humanos e os direitos fundamentais, uma vez que a maior parte das Constituições do segundo pós-guerra se inspirou tanto na Declaração Universal de 1948, quanto nos diversos documentos internacionais e regionais que as sucederam, de tal sorte que - no que diz com o conteúdo das declarações internacionais e dos textos constitucionais - está ocorrendo um processo de aproximação e harmonização, rumo ao que já está sendo denominado (e não exclusivamente - embora principalmente - , no campo dos direitos humanos e fundamentais) de um direito constitucional internacional.

Entretanto, entende-se que essa distinção entre direitos humanos e direitos fundamentais é de cunho meramente didático porque a essência desses direitos é a mesma, ou seja, eles visam à proteção da dignidade humana em sua integralidade, residindo sua diferenciação tão somente no grau de concreção positiva: positivação no âmbito do direito constitucional ou no direito internacional.

Após a Segunda Guerra Mundial — concomitantemente com a internacionalização dos direitos humanos e a constitucionalização ${ }^{(1)}$ dos direitos sociais, inclusive dos direitos trabalhistas, conhecida como Constitucionalismo Social ${ }^{(2)}$ - , consolidaram-se na ordem internacional os processos de integração regional, estando em evidência o Mercado Comum do Sul (MERCOSUL) na América Latina, mas já existiram outras tentativas de formação de blocos econômicos latino-americanos, tais como a Associação Latino-Americana de Livre Comércio (ALALC) criada em 18.02.1960; a Associação Latino-Americana de Integração (ALADI) constituída em 12.08.1980 e, recentemente, a União de Nações Sul-Americanas (UNASUL) cujo tratado constitutivo foi aprovado em 23.05.2008 na Reunião Extraordinária de Chefes de Estado e de Governo realizada em Brasília ${ }^{(3)}$.

(1) De acordo com Barroso (2010), "a ideia de constitucionalização do Direito [...] está associada a um efeito expansivo das normas constitucionais, cujo conteúdo material e axiológico se irradia, com força normativa, por todo o sistema jurídico. Os valores, os fins públicos e os comportamentos contemplados nos princípios e regras da Constituição passam a condicionar a validade e o sentido de todas as normas do direito infraconstitucional. Como intuitivo, a constitucionalização repercute sobre a atuação dos três Poderes, inclusive e notadamente nas suas relações com os particulares. Porém, mais original ainda: repercute, também, nas relações entre particulares".

(2) Conforme Rosa (2002, p. 18) aponta, "o constitucionalismo social nutriu-se, em seus primeiros tempos, em fontes normativas resultantes do clamor social, que acabou por deflagrar movimentos revolucionários com denominações diversas. Posteriormente, hierarquizou a legislação social já existente e, finalmente, acolheu princípios emanados das Declarações e Tratados Internacionais. Desta forma, foi se sedimentando com base em diretrizes muito precisas e de maneira quase uniforme em âmbito internacional. Um processo responsável em sua projeção pelo significativo reconhecimento dos postulados de justiça social no século XX. Seu papel foi de elemento transformador da ordem jurídica vigente, uma renovação substancial nos sistemas constitucionais de perfil liberal".

(3) Argentina, Bolívia, Chile, Equador, Guiana, Peru, Suriname, Uruguai e Venezuela já depositaram seus instrumentos de ratificação, completando o número mínimo de ratificações necessárias para a sua entrada em vigor o que ocorreu em 11.03.2011 (UNASUL, 2011). 
Normalmente, os blocos econômicos de integração regional - como é o caso do MERCOSUL - objetivam o fortalecimento econômico e político regional dos Estados-membros com vistas à maior competitividade no âmbito do comércio mundial. Assim, o termo "integração" implica em noções como interdependência, corresponsabilidade, complementaridade e, principalmente, solidariedade entre os Estados participantes do bloco, havendo, na ordem internacional contemporânea, um processo de mitigação da soberania $^{(4)}$ dos Estados nacionais em prol de acordos internacionais comuns e implementação de políticas externas e internas mais harmônicas.

Nesse contexto, o MERCOSUL se originou de diversas negociações entre o Brasil e a Argentina ocorridas durante a década de 1980, sendo impulsionadas pelo processo de redemocratização dos países latino-americanos que encerrou um longo período de governos autoritários. As relações conflituosas entre a Argentina e o Brasil se transformaram em relações internacionais pautadas na cooperação e permitiram, em 1985, a assinatura da Declaração de Iguaçu.

Em 1988, foi assinado o Tratado Bilateral de Integração, Cooperação e Desenvolvimento, prevendo a formação de um espaço econômico comum entre ambos os países e, em 1990, foi assinada a "Ata de Buenos Aires", dispondo acerca da constituição de um Mercado Comum. Finalmente, em 26 de março de 1991, o Paraguai e o Uruguai se associaram ao Brasil e à Argentina e manifestaram seu interesse em participar desse grupo, assinando o Tratado de Assunção que se constituiu no marco jurídico-institucional na criação do Mercado Comum do Sul. A Venezuela, em 04.07.2006, assinou o Protocolo de Adesão ao MERCOSUl e, até o presente momento, Bolívia, Chile, Peru, Colômbia e Equador estão na qualidade de países associados.

O Protocolo de Ouro Preto, assinado em 1994, dispôs sobre a estrutura institucional $^{(5)}$ do MERCOSUL, conferindo-lhe personalidade jurídica de Direito Público Internacional (art. 34) e estabeleceu que os Estados-partes se comprometeriam a adotar todas as medidas necessárias para assegurar, em seus respectivos territórios, o cumprimento das normas emanadas dos órgãos integrantes do bloco (art. 38).

O artigo 1ํㅡㄹ do Tratado de Assunção previu, dentre outros propósitos, que o MERCOSUL seria um mercado comum baseado na livre circulação de bens, serviços e

(4) Ferrajoli (2002, p. 39-40) preceitua que "a soberania, inclusive externa, do Estado — ao menos em princípio — deixa de ser uma liberdade absoluta e selvagem e se subordina, juridicamente, a duas normas fundamentais: o imperativo da paz e a tutela dos direitos humanos. [...] A soberania, que já se havia esvaziado até o ponto de dissolver-se na sua dimensão interna com o desenvolvimento do estado constitucional de direito, se esvanece também em sua dimensão externa na presença de um sistema de normas internacionais caracterizáveis como ius cogens, ou seja, como direito imediatamente vinculado para os Estados-membros. No novo ordenamento, são de fato sujeitos de direito internacional não somente os Estados, mas também os indivíduos e os povos: [...]".

(5) “Artigo 1․․ A estrutura institucional do MERCOSUL contará com os seguintes órgãos: I. O Conselho do Mercado Comum (CMC); II. O Grupo Mercado Comum (GMC); III. A Comissão de Comércio do MERCOSUL (CCM); IV. A Comissão Parlamentar Conjunta (CPC); V. O Foro Consultivo Econômico-Social (FCES); VI. A Secretaria Administrativa do MERCOSUL (SAM). Parágrafo único. Poderão ser criados, nos termos do presente Protocolo, os órgãos auxiliares que se fizerem necessários à consecução dos objetivos do processo de integração. Artigo 2ํㅗão órgãos com capacidade decisória, de natureza intergovernamental, o Conselho do Mercado Comum, o Grupo Mercado Comum e a Comissão de Comércio do MERCOSUL." (MERCOSUL (f), 2011) 
fatores produtivos mediante a eliminação dos direitos alfandegários e das restrições não tarifárias à circulação de mercadorias e de qualquer outra medida de efeito equivalente e baseado, também, na coordenação de políticas macroeconômicas e setoriais - de comércio exterior, agrícola, industrial, fiscal, monetária, cambial e de capitais, de outras que se acordem - a fim de assegurar condições adequadas de concorrência entre os Estados-partes.

O MERCOSUL assumiu, em sua origem, uma feição mais comercial com o desafio de sua conversão em mercado comum pela implantação de livre circulação de bens, serviços, capitais e pessoas. Na circulação de pessoas, estão incluídos consumidores e trabalhadores que possuem direitos a serem protegidos por meio de normas comuns um direito comum - entre os Estados-partes, o que ainda não há, e direitos a serem resguardados por um tribunal supranacional também inexistente no bloco mercosulista. Além disso, quando se pensa numa circulação ampla de bens, serviços, capitais e pessoas entre países diversos, necessariamente, haverá ilícitos penais cometidos que também devem possuir regulação e tutela específicas também ausentes atualmente no MERCOSUL. Todas essas questões extrapolam o aspecto puramente comercial que envolve os parceiros do bloco, sendo necessário se avançar mais na criação de instituições supranacionais.

As atividades dos seres humanos são exteriorizadas pelas relações entre os seus semelhantes ou de ações sobre os bens, sejam materiais ou imateriais, estando todas reguladas pelo direito no âmbito das sociedades em diferentes épocas históricas.

É certo que o direito se apodera do homem desde antes de seu nascimento e o mantém sob sua proteção até depois de sua morte. Mas, certo também é que, sempre e a todo instante, o considera como parte de uma comunhão, que é a sociedade, fora da qual o homem, civilmente, não poderia viver. Por isso, é que sociedade e direito forçosamente se pressupõem, não podendo existir aquela sem este, nem este sem aquela. Ubi societas ibi jus. Se a coexistência social resulta da natureza humana, também da natureza do homem, que Deus fez à sua semelhança, o direito decorre. (RÁO, 2005, p. 51-53.)

Portanto, ao longo da história e civilização humanas, o direito sempre esteve presente na forma escrita ou costumeira na vida de todos os povos e sociedades. No caso do MERCOSUL, verifica-se que os Estados-partes não se preocuparam com a tutela dos direitos da pessoa humana (civis, políticos, sociais, trabalhistas etc.) que permeiam o processo de integração latino-americana, não estando previstos nos tratados que fundamentaram a criação e a institucionalização do bloco.

Esse processo não é algo exclusivo do MERCOSUL, mas vem se repetindo com frequência no contexto dos processos de integração regional em função do significativo impacto da globalização econômica e da adoção de ações e políticas neoliberais, havendo um "esquecimento" ou mesmo um descaso proposital com o respeito, a promoção e a realização dos direitos do ser humano, principalmente dos direitos sociais e laborais. Sobre essa questão, Piovesan (2003, p. 67) dispõe:

Embora a formação de blocos econômicos de alcance regional, tanto na União Européia, como no MERCOSUL, tenha buscado não apenas a integração e cooperação de natureza 
econômica, mas posterior e paulatinamente a consolidação da democracia e a implementação dos direitos humanos nas respectivas regiões (o que se constata com maior evidência na União Européia e de forma ainda bastante incipiente no MERCOSUL), observa-se que as cláusulas democráticas de direitos humanos não foram incorporadas na agenda do processo de globalização econômica. Ao revés, a globalização econômica tem comprometido a vigência dos direitos humanos, em especial dos direitos sociais. Em face da indivisibilidade dos direitos humanos, como já mencionado, a violação aos direitos sociais acaba por implicar a violação aos direitos civis e políticos, o que resulta na fragilização da própria democracia. Testemunha-se, ainda, o impacto transformador e desagregador da transnacionalização dos mercados sobre as estruturas político-institucionais, na medida em que as decisões passam a ser tomadas no âmbito de organismos multilaterais e conglomerados multinacionais, com a substituição da política pelo mercado, enquanto instância decisória.

No caso específico dos direitos dos trabalhadores, é necessário destacar a aprovação no MERCOSUL, em 10 de dezembro de 1998, da Declaração Sociolaboral firmada por Argentina, Brasil, Paraguai e Uruguai, expressando a opção desses Estados para o desenvolvimento de um modelo de integração que fosse capaz de harmonizar desenvolvimento econômico e bem-estar social, enfocando o emprego produtivo nas políticas e programas a serem desenvolvidos no bloco.

Esse documento prevê a tutela dos seguintes direitos humanos trabalhistas (MERCOSULb, 2011): não discriminação no mercado de trabalho (art. $1^{\circ}$ ); promoção da igualdade entre todas as pessoas - portadores de necessidades, mulheres e homens (arts. $2^{\circ}$ e $3^{\circ}$ ); proteção aos trabalhadores migrantes e fronteiriços (art. $4^{\circ}$ ); eliminação do trabalho forçado (art. $5^{\circ}$ ); tutela do trabalho infantil e de menores (art. 6을 ; direito dos empregadores de organizar e dirigir tecnicamente a empresa em conformidade com a lei (art. $7^{\circ}$ ); liberdade de associação (art. $8^{\circ}$ ); liberdade sindical (art. 9ํㅜ); negociação coletiva (art. 10); garantia do direito de greve (art. 11); promoção e desenvolvimento de procedimentos preventivos e de autocomposição de conflitos (art. 12); promoção do diálogo social entre os Estados-partes (art. 13); fomento ao emprego para corrigir os desequilíbrios sociais e regionais (art. 14); proteção dos desempregados (art. 15); formação profissional e desenvolvimento de recursos humanos (art. 16); proteção da saúde e segurança no trabalho (ambiente de trabalho sadio e equilibrado) (art. 17); inspeção do trabalho (art. 18); e seguridade social (art. 19) ${ }^{(6)}$.

A Declaração Sociolaboral do MERCOSUL, por não ser um tratado internacional, não possuiria, a princípio, força normativa vinculante e coercitiva, sendo uma carta de intenções ou uma declaração de direitos. Entretanto, não se pode desprezá-la como norma integrante do Direito de Integração mercosulista, sobretudo em face de seu conteúdo protetivo de direitos humanos dos trabalhadores. Nesse sentido, Comparato (2007, p. 227) preceitua que "reconhece-se hoje, em toda a parte, que a vigência dos direitos humanos independe de sua declaração em constituições, leis e tratados internacionais, exatamente porque se está diante de exigências de respeito à dignidade humana, exercidas contra todos os poderes estabelecidos, oficiais ou não".

(6) Para mais detalhes sobre o trabalho digno no MERCOSUL, consulte GAMBA $(2010 ; 2011)$. 
Porém, apenas (ou principalmente) resta saber como esses direitos da pessoa humana poderão ser efetivamente implementados ou concretizados na realidade fática dos Estados do MERCOSUL, sendo o controle jurisdicional estatal - na figura de um Tribunal ou Corte de Justiça supranacional — uma proposta viável que pode (ou não) estar sendo construída pelo Projeto de Norma aprovado pelo PARLASUL.

Portanto, é necessário o estudo de alguns dos institutos jurídicos do Projeto da Corte de Justiça, ora aprovado no Parlamento mercosulista, com ênfase em: descrição e análise dos instrumentos jurídico-processuais que poderão ser impetrados por pessoas físicas e jurídicas perante esse órgão jurisdicional (ações de nulidade; ações por omissão; ações de descumprimento ou violação; ações por questão predominante/prejudicial) e análise dos limites e deficiências da competência em razão da matéria (ratione materiae) desta futura Corte, sobretudo na solução de controvérsias entre os Estados-partes e as pessoas físicas e jurídicas no âmbito trabalhista, criminal e dos direitos humanos.

\section{Perspectivas para a Implantação de um Tribunal Supranacional no MERCOSUl}

Em face da existência de normas internacionais de proteção aos direitos humanos, de cunho global e regional, e das ordens constitucionais dos Estados democráticos que também promoveram a valorização da dignidade da pessoa humana, mostra-se - como imperativo para a cooperação entre os povos e a manutenção da paz — a existência de controles jurisdicionais estatais do adimplemento e da correta aplicação dessas normas, sobretudo no âmbito dos processos de integração regional, sendo a criação de tribunais supranacionais um dos caminhos a ser adotado, além do campo político-diplomático.

No MERCOSUL, existem várias dificuldades para a implementação de um Tribunal ou Corte de Justiça supranacional, de natureza jurisdicional, para a solução dos conflitos que surjam no âmbito desse bloco de integração regional. Ele possui personalidade jurídica de Direito Público Internacional (arts. 34 e 35 do Protocolo de Ouro Preto ${ }^{(7)}$ ), mas não pode ser considerada, ainda, uma "comunidade", assumindo atualmente a feição de organização internacional de caráter intergovernamental porque as decisões só podem ser tomadas mediante o consenso dos Estados-partes.

Esse processo dificulta os avanços institucionais, inclusive para a adoção de ações e políticas públicas comuns e articuladas. Além disso, a falta de independência nas tomadas de decisões impede a consolidação no bloco de um Direito Comunitário ${ }^{(8)}$ -

(7) "Artigo 34. O MERCOSUL terá personalidade jurídica de Direito Internacional. Artigo 35. O MERCOSUL poderá, no uso de suas atribuições, praticar todos os atos necessários à realização de seus objetivos, em especial contratar, adquirir ou alienar bens móveis e imóveis, comparecer em juízo, conservar fundos e fazer transferência." (MERCOSUL, 2011f)

(8) Esse direito pressupõe um estágio bem avançado de integração entre os Estados, com delegação das soberanias nacionais para uma esfera político-jurídica supranacional. Segundo Lobo (2007, p. 139), "os tratados comunitários instituíram uma ordem jurídica própria, que se integra no sistema jurídico dos Estados-Membros e que se impõe aos órgãos jurisdicionais nacionais. [...] os princípios fundamentais do direito comunitário [são] [...] a autonomia do direito comunitário em relação aos direitos nacionais; o primado do direito comunitário sobre as normas nacionais; a inserção do direito comunitário nos ordenamentos jurídicos nacionais". 
direito comum aos Estados-partes e fundamentado na supranacionalidade - , havendo, apenas, normas que se aproximam de um Direito de Integração ${ }^{(9)}$.

Apesar do MERCOSUL ainda assumir uma feição intergovernamental em contraposição à necessária supranacionalidade e existir um Direito de Integração ao invés de um Direito Comunitário, isso não pode ser óbice a inviabilizar todo o processo de integração mercosulista que está inserido no âmbito do chamado "novo regionalismo" ou "regionalismo aberto" assim definido (CEPAL, 2000, p. 945):

[...] denomina-se "regionalismo aberto" o processo que surge ao serem conciliados dois fenômenos [...]: a interdependência nascida de acordos especiais de caráter preferencial e a que é basicamente impulsionada pelos sinais do mercado, resultantes da liberalização comercial em geral. O que se busca com o regionalismo aberto é que as políticas explícitas de integração sejam compatíveis com as políticas tendentes a elevar a competitividade internacional, além de complementares a elas. O que diferencia o regionalismo aberto da abertura e da promoção indiscriminada das exportações é que ele inclui um ingrediente preferencial, refletido nos acordos de integração e reforçado pela proximidade geográfica e pela afinidade cultural dos países da região.

A consolidação internacional desse regionalismo aberto também é apontada como favorável para impulsionar a integração regional na América Latina, favorecendo os acordos regionais entre os países.

Cabe ressaltar que o MERCOSUL não é um processo "descolado" dos objetivos integracionistas mais amplos que envolvem a América Latina porque foi criado sob o marco jurídico da Associação Latino-Americana de Integração (ALADI), sendo o Tratado de Assunção (1991) — celebrado entre Argentina, Brasil, Paraguai e Uruguai criando o MERCOSUL - , um caso de acordo de alcance parcial ${ }^{(10)}$ : o Acordo de Complementação Econômica (ACE) nำ 18.

Esses acordos de complementação econômica são instrumentos para os países-membros da ALADI realizarem acordos de alcance parcial, ou seja, acordos que não atingem todos os membros da Associação, o que promove contornos mais sólidos ao processo integracionista do MERCOSUL. Entretanto, a integração latino-americana e o MERCOSUL ainda esbarram na questão da reciprocidade no campo econômico, mais especificamente, para a implementação de políticas macroeconômicas coordenadas entre os países da região(11).

(9) Consoante dispõe Furlan (2008, p. 126), "é ele o conjunto de regras de direito das gentes formulado e aplicável, no seio de um processo de integração de Estados conformadores de uma pessoa jurídica de direito internacional, derivada da integração das partes e recepcionado nas respectivas ordens jurídicas internas. Alguns estudiosos consideram o direito da integração uma especialidade do direito internacional, outros, ao inverso, consideram-no uma especialidade do direito constitucional. Certo é que o direito da integração não é dotado de autonomia, diversamente [...] do direito comunitário".

(10) No âmbito da ALADI, há uma série de acordos: os regionais que são conformados pela totalidade dos países-membros e aqueles de alcance parcial firmados entre apenas alguns países-membros ou entre alguns países-membros e países não membros.

(11) Maiores detalhes em BRAGA, 2002. 
Ademais, em 2005, houve a constituição do Parlamento do MERCOSUL (PARLASUL) ${ }^{(12)}$ como órgão de representação dos povos, independente e autônomo, integrante da estrutura institucional do bloco, com sede em Assunção (Paraguai) e, mais recentemente, a aprovação de um projeto de norma de uma Corte de Justiça, sinalizando que o processo de integração regional mercosulista não morreu e está ganhando um "novo fôlego" rumo à constituição de uma comunidade latino-americana de nações. Silva (2003, p. 28) observa que o MERCOSUL caminha em direção a este processo:

[...] o MERCOSUL é certamente a organização regional mais tendencialmente voltada para a construção de uma comunidade, na medida em que evolui seguindo, bem de perto, o paradigma europeu. Se seu direito não tem ainda as características de um direito comunitário, bem se percebe nos seus tratados constitutivos aquela mesma preocupação de institucionalizar uma comunidade, delineando uma estrutura institucional semelhante à da Comunidade Européia [...].

Há vozes defendendo há muito tempo que o MERCOSUL deve se constituir num processo de integração regional mais amplo que ultrapasse os aspectos puramente comerciais, havendo o desenvolvimento de acordos políticos e normas jurídicas capazes de viabilizar a resolução de problemas comuns dos Estados-partes e dos povos mercosulistas mediante o estreitamento do vínculo de solidariedade e cooperação, consoante já apontou Garcia (2001, p. 16-18):

Desde logo, a finalidade de um "mercado comum" representa uma restrição bastante criticada: o MERCOSUL deverá ser, mais do que isso, o acesso a uma identidade latino-americana em tudo que, desde suas origens e por suas características comuns, deva ser conjuntamente fortalecido e defendido. [...]

Trata-se, portanto, no MERCOSUL, de um processo de integração regional ou parcializada de países, no que estes têm de comum nos seus interesses e dificuldades vindos da necessária convivência e, neste aspecto, demonstra-se bastante antigo, conforme aponta a História: o projeto da Companhia de Jesus, no século XVII, e outros.

Mas em que contexto isso vem a ocorrer? Caminha-se, na atualidade, por uma ideia de supranacionalidades, supra-ordenamento, tribunais internacionais. Internamente, enfrentam-se os conflitos do Direito Interno e do Direito Internacional: a prevalência de uma ou de outra norma, conforme se divide o monismo e o dualismo jurídicos. [...]

Externamente, as relações do MERCOSUL ressentem-se das divergências legislativas e da falta de legislação: só recentemente, por exemplo, o Decreto 3.196, de outubro de 1999, promulgou o Protocolo de Integração Educacional para prosseguimento de Estudos de Pós-graduação nas Universidades dos Países-membros do MERCOSUL, concluído em Forta-

(12) Em relação ao PARLASUL, é preciso destacar: "Art. 2ํ․ São propósitos do Parlamento: 1. Representar os povos do MERCOSUL, respeitando sua pluralidade ideológica e política. 2. Assumir a promoção e defesa permanente da democracia, da liberdade e da paz. 3. Promover o desenvolvimento sustentável da região com justiça social e respeito à diversidade cultural de suas populações. 4. Garantir a participação dos atores da sociedade civil no processo de integração. 5. Estimular a formação de uma consciência coletiva de valores cidadãos e comunitários para a integração. 6. Contribuir para consolidar a integração latino-americana mediante o aprofundamento e ampliação do MERCOSUL. 7. Promover a solidariedade e a cooperação regional e internacional." (MERCOSUL, 2011d) 
leza, 1996. Ou seja, o MERCOSUL se expande, mas encontra o problema das parcerias: certamente que o Brasil sustenta o MERCOSUL com sua capacitação geográfica (clima e solo) e pelas suas admiráveis potencialidades de economia e de mercado. Então, detém o dúplice encargo da manutenção do sistema e de enfrentar o temor, pelos seus parceiros, de um objetivo hegemônico. ${ }^{(13)}$

Especificamente a respeito dos mecanismos para a solução de controvérsias no bloco, está vigente o Protocolo de Olivos, assinado em 18.02.2002, que criou um Tribunal Permanente de Revisão para julgar, em nível recursal, as decisões proferidas pelos tribunais arbitrais ad hoc. O art. 55 do Protocolo de Olivos derrogou, a partir de sua vigência, o Protocolo de Brasília para a Solução de Controvérsias, adotado em 17 de dezembro de 1991, mas permitiu que as controvérsias iniciadas sob o regime deste protocolo e, ainda, não concluídas totalmente, continuassem sendo dirimidas por ele e seu regulamento.

Entretanto, apesar de ter conferido maior institucionalidade ao sistema de solução de controvérsias, disciplinando basicamente aquelas controvérsias surgidas no âmbito comercial e prevendo uma instância recursal para apreciar as decisões proferidas, o Protocolo de Olivos ainda manteve o sistema de arbitragem ad hoc, não instituindo no bloco um Tribunal Supranacional o que, atualmente, está sendo proposto pelo PARLASUL.

Para fins exemplificativos, sem se aprofundar no estudo porque fugiria aos limites do presente artigo, é preciso destacar que a União Europeia (UE) possui um Tribunal de Justiça ${ }^{(14)}$ — de caráter supranacional — direcionado para o respeito e aplicação do Direito Comunitário ou Direito da União e, ainda, para a tutela dos direitos dos cidadãos do bloco. O Tribunal de Justiça da UE possui três jurisdições, a saber: o Tribunal de Justiça, o Tribunal Geral e o Tribunal da Função Pública.

O Tribunal de Justiça foi criando ao longo dos anos, através da sua jurisprudência, a obrigação das administrações e dos juízes nacionais aplicarem plenamente o Direito da União no interior das respectivas esferas de competência e de protegerem os direitos conferidos por este aos cidadãos (aplicação direta do Direito da União), deixando de aplicar qualquer disposição contrária do direito nacional, seja ela anterior ou posterior à disposição da União (primado do Direito da União sobre o direito nacional). O Tribunal de Justiça atua igual-

(13) Posteriormente, com vistas ao fortalecimento da integração educacional, foram aprovados o Decreto Legislativo $\mathrm{n}$ 은 62 , de 28 de janeiro de 2004, que promulgou o Protocolo de Integração Educacional para o Prosseguimento de Estudos de Pós-graduação nas Universidades dos Países-membros do MERCOSUL e da República da Bolívia e o Decreto Legislativo nำ 924, de 16 de setembro de 2005, que promulgou o Protocolo de Integração Educacional para a Formação de Recursos Humanos no Nível de Pós-graduação entre os Estados-partes do MERCOSUL e da República da Bolívia (MERCOSUL, 2011a) (nota nossa).

(14) "O Tribunal de Justiça é composto por 27 juízes e 08 advogados-gerais. Os juízes e os advogados-gerais são designados de comum acordo pelos governos dos Estados-membros, após consulta de um comitê encarregado de dar parecer sobre a adequação dos candidatos propostos ao exercício das funções em causa. Os seus mandatos são de seis anos, renováveis. São escolhidos entre pessoas que ofereçam todas as garantias de independência e possuam a capacidade requerida para o exercício, nos respectivos países, de altas funções jurisdicionais ou que tenham reconhecida competência. Os advogados-gerais assistem o Tribunal, cabendo-lhes apresentar publicamente, com toda a imparcialidade e independência, pareceres jurídicos, denominados "conclusões", nos processos para os quais tenham sido nomeados. O Tribunal de Justiça pode funcionar em Tribunal Pleno, em Grande Secção com 13 juízes ou em seções de cinco ou de três juízes.” (UNIÃO EUROPEIA, 2012) 
mente em colaboração com o juiz nacional, juiz de direito comum do direito da União. Qualquer juiz nacional, chamado a conhecer de um litígio em que esteja em causa o Direito da União, pode, e por vezes deve, submeter questões prejudiciais ao Tribunal de Justiça. O Tribunal deve então dar a sua interpretação de uma disposição de direito da União ou fiscalizar a respectiva legalidade. (UNIÃO EUROPEIA, 2012)

A grande maioria dos acórdãos proferidos pelo Tribunal de Justiça da União Europeia tem consequências significativas na vida cotidiana de seus cidadãos, principalmente nas áreas mais importantes do Direito Comunitário como destacado a seguir (UNIÃO EUROPEIA, 2012):

a) livre circulação de mercadorias: desde o acórdão Cassis de Dijon, proferido em 1979, sobre o princípio da livre circulação de mercadorias, os comerciantes podem importar para o seu país qualquer produto proveniente de outro país da União na condição desse produto ter sido legalmente produzido e comercializado neste último país e razão imperiosa, por exemplo, à proteção da saúde ou do ambiente, não se pode opor à sua importação para o país de consumo;

b) livre circulação de pessoas: numerosos acórdãos foram proferidos nessa área. No acórdão Kraus (1993), o Tribunal de Justiça declarou que a situação de um cidadão comunitário, titular de um diploma universitário de pós-graduação obtido noutro Estado-membro da UE - o que lhe facilitaria o acesso a uma profissão ou o exercício de uma atividade econômica - , seria regulada pelo Direito Comunitário mesmo nas suas relações com o Estado-membro do qual é nacional. Assim, embora um Estado-membro possa exigir uma autorização administrativa para a utilização desse título em seu território, tal procedimento deve apenas verificar se o diploma em questão foi corretamente concedido. Outro acórdão muito conhecido é o Acórdão Bosman (1995) no qual o Tribunal de Justiça se pronunciou, a pedido de um órgão jurisdicional belga, sobre a compatibilidade de disposições adotadas por federações de futebol com a livre circulação de trabalhadores. Ele declarou que o desporto praticado a nível profissional é uma atividade econômica cujo exercício não pode ser obstaculizado mediante disposições que regulem a transferência de jogadores ou limitem o número de jogadores nacionais de outros Estados-membros. Acórdãos posteriores tornaram esta última consideração extensiva à situação de desportistas profissionais originários de países terceiros que assinaram com as Comunidades Europeias um acordo de associação (Acórdão Deutscher Handballbund, 2003) ou de parceria (Acórdão Simutenkov, 2005);

c) livre prestação de serviços: um acórdão de 1989 sobre a livre prestação de serviços tinha por objeto a situação de um turista britânico que tinha sido agredido e ferido com gravidade no metropolitano de Paris. Chamado a pronunciar-se por um órgão jurisdicional francês, o Tribunal de Justiça declarou que, enquanto turista, a referida pessoa se beneficiava de serviços fora do seu país, sendo-lhe aplicável o princípio da não discriminação em razão da nacionalidade consagrado no Direito Comunitário. Tinha, portanto, direito à mesma indemnização que um nacional francês (Acórdão Cowan). Chamado a pronunciar-se pelos órgãos jurisdicionais luxemburgueses, o Tribunal de Justiça declarou que uma legislação nacional que recusa a um beneficiário da segurança social o reembolso das despesas de um tratamento dentário com o fundamento de que foi efetuado noutro Estado-membro constitui entrave injustificado à livre prestação de serviços (Acórdão Kohll, 1998) e que a recusa de reembolso das despesas de compra de óculos no estrangeiro é considerada um entrave injustificado à livre circulação de mercadorias (Acórdão Decker, 1998); 
d) igualdade de tratamento e direitos sociais: uma hospedeira de bordo tinha intentado uma ação contra a sua entidade patronal em razão de discriminação na sua remuneração relativamente aos seus colegas do sexo masculino que efetuavam o mesmo trabalho. Chamado a conhecer do processo por um tribunal belga, o Tribunal de Justiça declarou, em 1976, que a disposição do Tratado que impunha o princípio da igualdade de remunerações entre trabalhadores femininos e masculinos pelo mesmo trabalho tinha efeito direto (Acórdão Defrenne). Ao interpretar as disposições comunitárias relativas à igualdade de tratamento entre homens e mulheres, o Tribunal de Justiça contribuiu para a proteção das mulheres contra o despedimento ligado à maternidade. Uma mulher que deixou de poder trabalhar em razão de dificuldades relacionadas com a sua gravidez foi despedida, em 1998, o Tribunal de Justiça declarou este despedimento contrário ao Direito comunitário. O despedimento de uma mulher durante a gravidez por faltas resultantes de uma doença relacionada com a própria gravidez constitui discriminação em razão do sexo, sendo proibida (Acórdão Brown). A fim de garantir a proteção da segurança e da saúde dos trabalhadores, é necessário que estes possam gozar férias anuais pagas. Em 1999, o sindicato britânico BECTU contestou a legislação britânica que privava os trabalhadores desse direito com contratos de curta duração sob o fundamento de que não era compatível com uma diretiva comunitária relativa à organização do tempo de trabalho. O Tribunal de Justiça concluiu (Acórdão BECTU, 2001) que o direito a férias anuais pagas é um direito social diretamente conferido a todos os trabalhadores pelo Direito Comunitário e dele nenhum trabalhador pode ser privado;

e) direitos fundamentais: ao decidir que o respeito aos direitos fundamentais é parte integrante dos princípios gerais de direito cujo respeito lhe incumbe garantir, o Tribunal de Justiça contribuiu de forma considerável para o aumento dos níveis de proteção desses direitos. Ele se inspirou nas tradições constitucionais comuns aos Estados-membros e nos instrumentos internacionais sobre a proteção dos direitos humanos, designadamente na Convenção Europeia dos Direitos do Homem, nos quais os Estados-membros cooperaram ou aos quais aderiram. A partir da entrada em vigor do Tratado de Lisboa, o Tribunal poderá aplicar e interpretar a Carta dos Direitos Fundamentais da União Europeia, de 07 de dezembro de 2000, à qual o Tratado de Lisboa reconhece o mesmo valor jurídico que os Tratados. Após diversos atentados terroristas contra polícias, foi introduzido na Irlanda do Norte o porte de arma das forças policiais. Todavia, por razões de segurança pública, o porte de arma não foi autorizado às mulheres policiais com base num certificado emitido pelo ministério competente e insusceptível de recurso para os tribunais. Consequentemente, deixaram de ser propostos empregos às mulheres em regime de horário completo na polícia da Irlanda do Norte. Chamado a pronunciar-se por um órgão jurisdicional do Reino Unido, o Tribunal de Justiça declarou que a exclusão de qualquer poder de fiscalização por parte das autoridades judiciais sobre um certificado de uma autoridade nacional se opõe ao princípio do recurso jurisdicional efetivo reconhecido a qualquer pessoa que se considere lesada por discriminação em razão do sexo (Acórdão Johnston, 1986);

f) cidadania da União: o Tribunal de Justiça confirmou que a cidadania da União que, segundo o Tratado sobre o Funcionamento da União Europeia, é um direito reconhecido a qualquer pessoa que tenha a nacionalidade de um Estado-membro, implica o direito de residir no território de outro Estado-membro. Assim, um nacional menor de um Estado-membro, coberto por um seguro de doença e dispondo de recursos suficientes, beneficia-se igualmente desse direito de residência. O Tribunal sublinhou que o Direito Comunitário não exige que o próprio menor disponha dos recursos necessários e a recusa de conceder ao mesmo tempo à mãe deste, nacional de um país terceiro, um direito de residência privaria de qualquer efeito útil esse direito de residência do menor (Acórdão Zhu e Chen, 2004). 
No mesmo acórdão, o Tribunal de Justiça esclareceu que, mesmo no caso da aquisição da nacionalidade de um Estado-membro ter por objetivo obter um direito de residência ao abrigo do Direito Comunitário a favor de um nacional de um terceiro Estado, um Estado-membro não pode restringir os efeitos da atribuição da nacionalidade de outro Estado.

Portanto, esses exemplos evidenciam que o Tribunal de Justiça da União Europeia possui competência ampla para apreciar todas as espécies de litígios que impactam na vida dos cidadãos (pessoas físicas) e violem os seus direitos humanos, inclusive ele atua disciplinando todas as relações sociais e jurídicas firmadas no bloco sob o amparo do Direito Comunitário, prevalecendo em face do direito nacional de cada Estado-membro, não havendo restrição de sua atuação a questões de cunho comercial.

Então, a partir do exemplo do Tribunal de Justiça da UE, resta verificar se a proposta de Corte de Justiça para o MERCOSUL permitiria a formação de um órgão jurisdicional e supranacional com competência ampla e instrumentos jurídico-processuais eficazes para garantir a aplicação e a interpretação uniforme de normas entre os países mercosulistas, sobretudo se houver a violação dos direitos da pessoa humana na qualidade de consumidores, trabalhadores ou "cidadãos" do bloco (uma possível cidadania supranacional a ser construída).

\section{Jurisdição, CompetênCia e InStrumentos Jurídico-processuais da "Futura" Corte de Justiça do MERCOSUL ${ }^{(15)}$}

A Exposição de Motivos do Projeto de Norma da Corte de Justiça do MERCOSUL aponta:

É um momento propício para a criação de uma Corte de Justiça, como mostra os progressos alcançados pelo bloco em outras áreas, que deve estar acompanhado pelos avanços em matéria de solução de controvérsias a fim de garantir a certeza e segurança jurídicas. [...] tanto o Parlamento do MERCOSUL (Declarações nos 23/2008 e 01/2009) como os Tribunais Supremos de Justiça nacionais, no marco do Foro Permanente das Cortes Supremas do MERCOSUL, se manifestaram sobre a necessidade de criar um órgão judicial regional para o bloco. (MERCOSUL, 2011c, p. 02-03, tradução nossa)

Porém, para compreender alguns institutos jurídicos analisados no presente estudo, é preciso, primeiramente, elucidar os conceitos de jurisdição e de competência para apreendê-los no âmbito deste projeto de Corte de Justiça.

Nos primórdios da sociedade, os homens resolviam seus conflitos por suas próprias mãos, empregando a violência e a força física. Com a evolução da sociedade, o Estado tornou-se mais presente na solução dos conflitos e atraiu para si essa compe-

(15) Para facilitar a compreensão dos institutos jurídicos analisados, realizou-se a tradução direta do texto de lei em idioma espanhol, indicando-se a qual artigo do projeto de norma se está fazendo a interpretação, pois a transcrição literal de grandes trechos da norma tornaria maçante a leitura do presente trabalho e extrapolaria os limites de páginas estabelecidos pela Comissão Editorial dos Cadernos PROLAM. 
tência no intuito de buscar o bem comum e a paz social. Esse poder que o Estado se investe na solução dos conflitos é chamado jurisdição.

No dicionário de Língua Portuguesa (2012), a palavra jurisdição vem do latim iuris com o significado de direito e dictio do verbo dicere que significa dicção. Portanto, jurisdição é o poder no qual o juiz está investido pelo Estado para dizer o direito nos casos concretos. De acordo com Wambier (2000, p. 38), a jurisdição é entendida como:

[...] a função que consiste, primordialmente, em resolver os conflitos que a ela sejam apresentados pelas pessoas, naturais ou jurídicas (e também pelos entes despersonalizados, tais como o espólio, a massa falida e o condomínio), em lugar dos interessados, por meio da aplicação de uma solução prevista pelo sistema jurídico. Por solução do sistema, entendemos aquela prevista pela função normatizadora do Direito, esta consistente em regular a apropriação dos bens da vida pelas pessoas, mediante o uso de um sistema de comandos coativos ou sancionatórios, de sorte que seja possível alcançar soluções compatíveis com a necessidade de manutenção da paz social.

Portanto, a jurisdição é uma das formas de exercício do poder estatal, mas é necessário que esse exercício (atividade jurisdicional) seja dividido entre os órgãos componentes do Poder Judiciário — por exemplo: Justiça do Trabalho, Justiça Militar, Justiça Eleitoral, Justiça Comum etc. - seguindo algumas normas de competência. Assim, a competência pode ser conceituada como o instituto jurídico que define o âmbito de exercício da atividade jurisdicional a cada órgão componente do Poder Judiciário.

O poder estatal da jurisdição é indivisível e indelegável sob o ponto de vista do Estado em relação a outros entes, mas, em relação ao Estado em si mesmo, é necessário encontrar critérios que possibilitem o exercício racional do poder. Sob o ângulo funcional, a competência nada mais é do que o princípio da divisão social do trabalho aplicado à jurisdição. Trata-se de um critério de racionalização de serviço e distribuição de tarefas, como qualquer outro em qualquer grupo humano que trabalhe com certo objetivo. Razões de ordem prática obrigam o Estado a distribuir o poder jurisdicional entre vários juízes $e$ tribunais, visto não ser possível que um só órgão conheça todos os litígios e resolva todas as causas. Essa distribuição de poder obedece a certos critérios, visando a atender não só os interesses do Estado (Poder Judiciário), mas também o particular. Todos os juízes exercem a jurisdição numa certa medida e em certos limites. (ARAÚJO, 2005, p. 115, destaque nosso)

No caso específico da proposta de Corte de Justiça para o MERCOSUL, serão analisados alguns instrumentos jurídico-processuais que poderão ser impetrados perante esse órgão jurisdicional de caráter supranacional e, em específico, a sua competência em razão da matéria (ratione materiae).

O projeto propõe a criação da Corte de Justiça como órgão judicial, com jurisdição própria e independente e com organização e competências para garantir a aplicação e a interpretação uniforme das normas no bloco (art. $1^{\circ}$ ).

A Corte de Justiça estará integrada por um número de juízes igual ao dos Estados-partes e seus respectivos suplentes. Esses juízes serão nacionais dos Estados. O Conselho do Mercado Comum com o prévio aceite do Parlamento do MERCOSUL modificará o número de juízes e criará o cargo de Advogado-Geral (art. 2º). 
Os juízes da Corte teriam absoluta independência no exercício de suas funções e não poderiam solicitar e nem aceitar instruções de nenhum governo ou organismo e se absteriam de qualquer atuação incompatível com o caráter e a independência que o cargo impusesse (art. $3^{\circ}$ ).

Os Estados-partes deverão outorgar à Corte de Justiça todas as facilidades necessárias para o adequado cumprimento de suas funções (art. 11.1), de modo que essa Corte e seus juízes gozarão no território de todos os Estados-partes das imunidades e dos privilégios reconhecidos pelos usos internacionais e, em particular, pela Convenção de Viena sobre Relações Diplomáticas, incluindo inviolabilidade de seus arquivos e correspondências oficiais (art. 11.2).

A Corte de Justiça do MERCOSUL irá dirimir, mediante arbitragem, as controvérsias surgidas pela aplicação ou interpretação de contratos, convênios ou acordos subscritos por órgãos do MERCOSUL (art. 40). Os Estados-partes não submeterão nenhuma controvérsia que surja das normas de direito do MERCOSUL a nenhum outro tribunal, sistema de arbitragem ou procedimento distinto daqueles contemplados no protocolo constitutivo dessa Corte de Justiça (art. 47).

No âmbito da competência em razão da matéria (ratione materiae) dessa Corte de Justiça, o projeto propõe a apreciação de algumas ações processuais específicas que contribuiriam para a consolidação das normas mercosulistas e dos direitos dos cidadãos, destacando-se no presente estudo, dentre outras existentes, as ações de nulidade (arts. 17-21), as ações por omissão (arts. 22-23), as ações de descumprimento ou violação (arts. 24-32) e as ações por questão prejudicial ou predominante (arts. 33-39), ou seja, questionamentos realizados. O projeto de norma também propõe outros procedimentos que poderão ser apreciados pela Corte de Justiça do MERCOSUL, tais como: a exceção de ilegalidade, a etapa de cumprimento de sentença, a competência arbitral de caráter facultativo para as partes, as medidas cautelares etc.

Nas ações de nulidade, a Corte de Justiça poderá declarar a nulidade das decisões do Conselho do Mercado Comum, de Resoluções do Grupo Mercado Comum, de Diretivas da Comissão de Comércio do MERCOSUL e demais normas do bloco editadas pelos órgãos regionais as quais sejam de direito originário, aprovadas ou acordadas com violação das normas que conformam o direito mercosulista, inclusive por desvio de poder (art. 17.1). Os legitimados ativos para a propositura dessas ações seriam qualquer Estado-parte, o Parlamento do MERCOSUL, o Conselho do Mercado Comum, o Grupo Mercado Comum, a Comissão de Comércio do MERCOSUL, a Secretaria do MERCOSUL e as pessoas físicas e jurídicas quando as normas afetem seus direitos subjetivos ou seus interesses legítimos (art. 17.2).

As ações por omissão poderiam ser propostas quando o Parlamento do MERCOSUL, o Conselho do Mercado Comum, o Grupo Mercado Comum, a Comissão de Comércio ou sua Secretaria se abstivessem de adotar medida ou de cumprir atividade, violando uma obrigação emanada do direito mercosulista. Ditos órgãos, os Estados-partes ou as pessoas físicas ou jurídicas afetadas em seus direitos subjetivos ou seus interesses legítimos poderão requerer o cumprimento da obrigação como legitimados ativos (art. 22.1). Se a Corte de Justiça admitir a ação por omissão, emitirá a sentença correspondente 
com base na documentação técnica existente, os antecedentes do caso e as explicações do órgão demandado, estabelecendo a forma, modalidade e prazo para que referido órgão cumpra a obrigação (art. 23).

As ações de descumprimento ou violação poderão ser propostas perante a Corte de Justiça no caso em que o Estado-parte tenha incorrido em violação das obrigações emanadas do direito mercosulista. A ação de violação poderá ser iniciada pelos Estados-partes, pelo Parlamento do MERCOSUL, pela Secretaria do MERCOSUL e pelas pessoas físicas ou jurídicas (arts. 24.1 e 24.2). Assim, de modo inovador, o projeto concede individualmente às pessoas capacidade processual e postulatória em nível internacional.

Então, as pessoas (físicas ou jurídicas) afetadas em seus direitos pela violação pelos Estados-partes das obrigações emanadas das normas mercosulitas poderão iniciar a ação de descumprimento (art. 27) perante a Corte de Justiça seguindo os procedimentos previstos nos incisos 1 a 3 do art. 26. A sentença de descumprimento a ser proferida pela Corte de Justiça se constituirá em título executivo para que essas pessoas possam solicitar aos juízes nacionais a indenização por danos e prejuízos sofridos (art. 31).

Porém, se elas optarem por essa via — a ação de descumprimento —, não poderão, com fundamento na mesma causa, utilizar-se de outros meios processuais mediante os juízes nacionais de seus países os quais seriam competentes para a solução da controvérsia no âmbito do direito interno (arts. 27.2 e 32). A jurisdição da Corte de Justiça é exclusiva e excludente, conforme termos utilizados na Seção "Fundamentos", parte integrante do próprio projeto de norma.

Evidencia-se, neste particular, um retrocesso nas garantias individuais dos cidadãos e do acesso à Justiça, afrontando os princípios da subsidiariedade e da complementari$\operatorname{dade}^{(16)}$ que norteiam a implantação de tribunais internacionais com caráter supranacional,

(16) Montal (2009, p. 171-172 ep. 175, negrito nosso) discorre sobre os princípios da subsidiariedade e da complementaridade norteadores da jurisdição internacional, exemplificando com os casos da Corte Internacional de Justiça ou Corte de Haia e do Tribunal Penal Internacional, in verbis: "Com efeito, atualmente existem, no plano internacional, órgãos jurisdicionais cuja finalidade centra-se na apreciação dos casos de violação de direitos humanos ocorridos no âmbito interno dos Estados-membros. Exemplifica-se com a Corte Internacional de Justiça dentro do sistema global; no sistema regional de proteção aos direitos humanos, há Corte Interamericana de Direitos Humanos e, no âmbito do direito humanitário, há o Tribunal Penal Internacional. O sistema tem caráter complementar, subsidiário, vale dizer, a atuação de tais órgãos fica subordinada ao esgotamento dos recursos internos ou quando o sistema judicial do país mostra-se ineficaze inoperante. É certo que o sistema deve ser aperfeiçoado, por exemplo, somente os Estados são partes em questões perante a Corte Internacional de Justiça, conforme artigo 34.1 do Estatuto da Corte: 'só os Estados poderão ser partes em questões perante a Corte. Ademais, nem todos os Tratados Internacionais de Direitos Humanos trazem a previsão do direito de petição do indivíduo que teve seu direito violado. [...] O Tribunal Penal Internacional tem sua atuação pautada em princípios fundamentais, dentre os quais se destaca o princípio da complementaridade, já referido em momento anterior. Por este princípio o Tribunal somente tem atuação se o Estado não iniciou processo ou, ainda que iniciado, teve por intuito subtrair o acusado à justiça ou mitigar-lhe a sanção. Assim, compete primeiramente aos próprios Estados o dever de reprimir todos os crimes tipificados no Estatu to até mesmo para que a sanção seja mais eficaz. Ademais, o TPI tem atuação subsidiária, agindo principalmente quando existe omissão ou inação do Estado. Portanto, não há interferência indevida nos sistemas judiciais nacionais que continuam com a responsabilidade primária de investigar e processar os crimes. Esse tribunal possui, assim, caráter excepcional e complementar, sendo que sua jurisdição aplica-se apenas aos crimes extremamente graves nele definidos. O TPI tem caráter excepcional e complementar, e sua jurisdição, além de aplicar-se apenas aos crimes de extrema gravidade nele definidos, somente pode ser admitida nos casos em que restar demonstrado a incapacidade ou a falta de disposição do Estado em processar os responsáveis." 
como é o caso dessa proposta de Corte de Justiça para o MERCOSUL. Os Estados, as pessoas físicas, as pessoas jurídicas, enfim, todo aquele jurisdicionado que busca a atuação de tribunais internacionais não deve ficar impedido de esgotar a jurisdição nacional de seu próprio país no amparo de seus direitos, pois essa sistemática torna ineficaz e inoperante a tutela do tribunal internacional, sobretudo quando se trata de direitos humanos. Conforme ressalta Piovesan (2003, p. 42-43):

Fortalece-se, assim, a ideia de que a proteção dos direitos humanos não deve se reduzir ao domínio reservado do Estado, isto é, não deve se restringir à competência nacional exclusiva ou à jurisdição doméstica exclusiva, porque revela tema de legítimo interesse internacional. Por sua vez, esta concepção inovadora aponta a duas importantes consequências:

1. a revisão da noção tradicional de soberania absoluta do Estado, que passa a sofrer um processo de relativização, na medida em que são admitidas intervenções no plano nacional em prol da proteção dos direitos humanos; isto é, permitem-se formas de monitoramento e responsabilização internacional, quando os direitos humanos forem violados;

2. a cristalização da ideia de que o indivíduo deve ter direitos protegidos na esfera internacional, na condição de sujeito de direito.

Prenuncia-se, desse modo, o fim da era em que a forma pela qual o Estado tratava seus nacionais era concebida como um problema de jurisdição doméstica, decorrência de sua soberania.

Dessa maneira, neste aspecto, o projeto de norma da Corte de Justiça do MERCOSUL apresenta significativo retrocesso, pois apesar de elevar as pessoas físicas e jurídicas à condição de legitimados ativos com capacidade processual e postulatória em nível internacional para as ações de descumprimento ou violação de direitos — instrumentos importantes que poderiam ser usados no monitoramento de violações aos direitos humanos - , concomitantemente, limita o direito humano de acesso à Justiça e o direito de ação de quaisquer cidadãos, ou melhor, a pessoa humana incluindo nacionais e estrangeiros dos países-membros do bloco, de modo que eles devem optar pela jurisdição nacional de seus países ou pela jurisdição internacional da Corte de Justiça do MERCOSUL. Isso é um contrassenso.

Finalmente, as ações por questão predominante/prejudicial serão utilizadas normalmente como mecanismo de consulta, obrigatório em certas ocasiões, de determinados órgãos do bloco e, principalmente, dos juízes e tribunais dos Estados-partes. Neste caso, a Corte de Justiça responderá pelas questões dominantes sobre a interpretação ou a validade das normas do MERCOSUL que sejam levantadas diretamente pelos órgãos jurisdicionais nacionais, de ofício ou por pedido da parte com o fim de assegurar sua aplicação uniforme no território dos Estados-partes (art. 33), mas o órgão jurisdicional nacional que requereu a consulta deverá adotar em sua sentença a resposta fornecida pela Corte (art. 36).

O Parlamento do MERCOSUL, o Conselho do Mercado Comum, o Grupo Mercado Comum, a Comissão de Comércio do MERCOSUL e a Secretaria do MERCOSUL poderão apresentar as questões dominantes sobre a interpretação ou a validade das normas do MERCOSUL perante a Corte de Justiça (art. 38), porém, as pessoas físicas e jurídicas não foram incluídas no rol dos legitimados ativos, representando um retrocesso neste aspecto 
particular, principalmente pelo fato de que nessas ações se questionará a interpretação e a validade do próprio direito mercosulista, sendo os cidadãos os sujeitos mais indicados para esse questionamento, sobretudo porque serão juridicamente atingidos pelas decisões a serem adotadas pela Corte. Também neste aspecto se mostra falho o projeto.

Em relação à competência em razão da matéria (ratione materiae), o projeto de norma trata na Seção VI da "Jurisdição Laboral", mas limita a atuação da Corte de Justiça para conhecer apenas as controvérsias administrativo-laborais que sejam suscitadas entre os órgãos do MERCOSUL e seus respectivos funcionários ou pessoas contratadas pelos mesmos para obras e serviços determinados (art. 42).

Logo, a Corte resolverá tão somente litígios de cunho meramente administrativo (relação jurídico-administrativa), não tendo competência em relação à solução de conflitos oriundos das relações de trabalho propriamente ditas, existentes nos Estados-partes, ou seja, os litígios que envolvam a prestação de trabalho humano (subordinado ou não) ${ }^{(17)}$, tais como: o trabalho autônomo, o temporário, o cooperado, o doméstico, o contrato de empreitada, o contrato de representação comercial, as terceirizações, as lides intersindicais etc. atinentes efetivamente ao mundo do trabalho.

A Corte de Justiça, ora proposta, não se propõe a resolver os conflitos que efetivamente envolvam as relações de trabalho que poderiam ser suscitados em três ordens: 1) entre os Estados-partes; 2) entre os Estados-partes e os particulares (pessoas físicas ou jurídicas); e 3) entre os particulares que, na qualidade de sujeitos de direito internacional, possuiriam legitimidade (capacidade processual e postulatória em nível internacional) para reclamar, mediante queixas e petições individuais, a violação de seus direitos humanos perante a Corte.

Portanto, o projeto de norma para a instauração da Corte de Justiça do MERCOSUL cria uma jurisdição supranacional "incompleta" com competência limitada porque não resolverá todas as espécies de litígios que poderão se constituir no bloco, principalmente se envolverem questões atinentes aos direitos humanos trabalhistas e as relações de trabalho propriamente ditas.

A competência ratione materiae dessa Corte também não abrangerá as demandas no âmbito penal ainda que os crimes tenham caráter transnacional, como, por exemplo, os crimes de tráfico de mulheres e crianças para exploração sexual; tráfico de entorpecentes, armas e órgãos; lavagem de capitais; crime de redução à condição análoga à

(17) A relação de trabalho possui definição mais ampla do que a relação de emprego, pois abrange, além desta, outras relações de trabalho remuneradas com graus variados de subordinação e informalidade; logo, toda relação de emprego é uma relação de trabalho, mas nem toda relação de trabalho é uma relação de emprego. Leite (2007, p. 198) apresenta a distinção entre relação de trabalho e relação de emprego: "Relação de trabalho é aquela que diz respeito, repise-se, a toda e qualquer atividade humana em que haja prestação de trabalho, como a relação de trabalho: autônomo, eventual, de empreitada, avulso, cooperado, doméstico, de representação comercial, temporário, sob a forma de estágio, etc. Há, pois, a relação de trabalho pela presença de três elementos: o prestador do serviço, o trabalho (subordinado ou não) e o tomador de serviço. Já a relação de emprego ocupa-se de um tipo específico desta atividade humana: o trabalho subordinado, prestado por um tipo especial de trabalhador: o empregado. Aqui, o que importa é a relação jurídica existente entre o empregado e o empregador (mesmo quando este seja pessoa de direito público interno ou externo), para efeito de aplicação do Direito do Trabalho. Três, portanto, são os elementos da relação de emprego: o empregado, o emprego e o empregador." 
de trabalho escravo (art. 149 do Código Penal Brasileiro - $\mathrm{CPB}^{(18)}$ ); crime de assédio sexual no ambiente de trabalho (art. 216-A do $\mathrm{CPB}^{(19)}$ ) e os chamados crimes contra a Organização do Trabalho (arts. 197 a 207 do CPB $^{(20)}$ ) — aliciamento de trabalhadores para o fim de emigração ou no território nacional, frustração de direito assegurado por lei trabalhista, atentado contra a liberdade de trabalho, dentre outros que podem possuir descrição específica dos fatos delituosos (tipificação penal) e diferentes penas em cada Estado integrante do MERCOSUL.

No intuito de suprir essa ausência de competência para os litígios penais, a Ordem dos Advogados do Brasil — Seção de São Paulo criou um grupo de estudos que elaborou um projeto específico para a criação do "Tribunal Penal do MERCOSUL" que foi entregue no dia 19 de março de 2012 ao embaixador do Brasil no bloco, Regis Arslanian, em Montevidéu (OAB, 2012).

Segundo informações da OAB/SP, o bloco necessita deste tribunal penal porque "o Brasil, a Argentina, o Paraguai e o Uruguai já reconheceram a jurisdição do Tribunal Penal Internacional sobre crimes de maior gravidade e o Estatuto de Roma, concordando com extradição de cidadãos acusados ao Tribunal Penal Internacional. O anteprojeto prevê que a nova Corte seja composta por ao menos 24 juízes com mandato de cinco anos, indicados pelos Estados-Partes — oito juízes de direito, oito advogados e oito representantes do Ministério Público, todos com pelo menos dez anos de profissão,

(18) "Art. 149. Reduzir alguém a condição análoga à de escravo, quer submetendo-o a trabalhos forçados ou a jornada exaustiva, quer sujeitando-o a condições degradantes de trabalho, quer restringindo, por qualquer meio, sua locomoção em razão de dívida contraída com o empregador ou preposto: Pena — reclusão, de dois a oito anos, e multa, além da pena correspondente à violência. § IํNas mesmas penas incorre quem: I — cerceia o uso de qualquer meio de transporte por parte do trabalhador, com o fim de retê-lo no local de trabalho; II — mantém vigilância ostensiva no local de trabalho ou se apodera de documentos ou objetos pessoais do trabalhador, com o fim de retê-lo no local de trabalho. § $2^{\circ} \mathrm{A}$ pena é aumentada de metade, se o crime é cometido: I — contra criança ou adolescente; II — por motivo de preconceito de raça, cor, etnia, religião ou origem." (BRASIL, 2012)

(19) "Art. 216-A. Constranger alguém com o intuito de obter vantagem ou favorecimento sexual, prevalecendo-se o agente da sua condição de superior hierárquico ou ascendência inerentes ao exercício de emprego, cargo ou função: Pena — detenção, de 1 (um) a 2 (dois) anos. $§ 2^{\circ}$ A pena é aumentada em até um terço se a vítima é menor de 18 (dezoito) anos. (BRASIL, 2012)

(20) "Atentado contra a liberdade de trabalho: Art. 197. Constranger alguém, mediante violência ou grave ameaça: I — a exercer ou não exercer arte, ofício, profissão ou indústria, ou a trabalhar ou não trabalhar durante certo período ou em determinados dias: Pena — detenção, de um mês a um ano, e multa, além da pena correspondente à violência; II — a abrir ou fechar o seu estabelecimento de trabalho, ou a participar de parede ou paralisação de atividade econômica: Pena - detenção, de três meses a um ano, e multa, além da pena correspondente à violência; Atentado contra a liberdade de contrato de trabalho e boicotagem violenta: Art. 198. Constranger alguém, mediante violência ou grave ameaça, a celebrar contrato de trabalho, ou a não fornecer a outrem ou não adquirir de outrem matéria-prima ou produto industrial ou agrícola: Pena — detenção, de um mês a um ano, e multa, além da pena correspondente à violência; Atentado contra a liberdade de associação: Art. 199. Constranger alguém, mediante violência ou grave ameaça, a participar ou deixar de participar de determinado sindicato ou associação profissional: Pena — detenção, de um mês a um ano, e multa, além da pena correspondente à violência; [...] Aliciamento para o fim de emigração: Art. 206. Recrutar trabalhadores, mediante fraude, com o fim de levá-los para território estrangeiro. Pena — detenção, de 1 (um) a 3 (três) anos e multa; Aliciamento de trabalhadores de um local para outro do território nacional: Art. 207. Aliciar trabalhadores, com o fim de levá-los de uma para outra localidade do território nacional: Pena — detenção de um a três anos, e multa. $\S 1$ Incorre na mesma pena quem recrutar trabalhadores fora da localidade de execução do trabalho, dentro do território nacional, mediante fraude ou cobrança de qualquer quantia do trabalhador, ou, ainda, não assegurar condições do seu retorno ao local de origem. § 2ํA pena é aumentada de um sexto a um terço se a vítima é menor de dezoito anos, idosa, gestante, indígena ou portadora de deficiência física ou mental." (BRASIL, 2012) 
notório saber jurídico e reputação ilibada. Teriam imunidades como Diplomatas. Os Estados-partes arcariam com os custos de instalação da corte, até que o Fundo de Convergência Estrutural do MERCOSUL assumisse o encargo. Após criado o Tribunal Penal do MERCOSUL, [haveria] a elaboração das normas penais, processuais penais e de execução penal do MERCOSUL, com a cooperação dos Estados-Partes" (JUSCLIP, 2012).

A proposta da OAB/SP para a criação do Tribunal Penal do MERCOSUL demonstra, mais uma vez, que o projeto de norma "MERCOSUR/PM/PN 02/2010" aprovado pelo PARLASUL possui jurisdição supranacional incompleta e competência ratione materiae limitada, principalmente ao tratar de litígios que envolvam a temática dos direitos humanos. Entende-se, inclusive, que a criação no MERCOSUL de um tribunal especial para tratar apenas de lides criminais, poderá enfraquecer a proposta de criação de uma "instância jurisdicional comunitária" que garanta a aplicação e a interpretação uniforme das normas no bloco. Seria mais adequado que as lides penais passassem a integrar a competência dessa Corte de Justiça do MERCOSUL, mediante uma emenda ao projeto de norma já aprovado no PARLASUL, ao invés de se criar outro tribunal para o bloco conforme a proposta da OAB/SP.

Portanto, as lides a serem apreciadas no âmbito da atual proposta de Corte de Justiça do MERCOSUL estarão mais relacionadas às questões administrativas e ao comércio internacional entre os Estados integrantes do bloco e entre particulares, normalmente empresas, não havendo o estabelecimento de uma competência para a apreciação de litígios estritamente penais/criminais ou oriundos de relações de trabalho ou, ainda, para a tutela dos direitos (civis, sociais etc.) da pessoa humana de um modo mais amplo, mantendo-se as lacunas social e jurídica existentes no campo do controle jurisdicional mercosulista. Em sentido semelhante, Ramos (2008, p. 368-369, grifo nosso) preleciona:

[...] o desenvolvimento do processo de integração do MERCOSUL expõe a importância de uma defesa endógena de direitos humanos. Os motivos são variados [...]: 1) demonstrar aos Supremos Tribunais dos Estados a existência de uma proteção equivalente de direitos humanos, 2) zelar pelo cumprimento do rol de direitos já previstos em tratados internacionais de direitos humanos (em especial o da Convenção Americana de Direitos Humanos, evitando a responsabilização internacional dos Estados membros perante a Corte de San José) e, finalmente, 3) dotar o processo de integração de legitimidade interna e externa. [...] Claro que, na ausência de uma Carta mercosulista de direitos fundamentais ou de um tribunal permanente no MERCOSUL de amplo acesso, urge suprir tais lacunas com o que existe atualmente tanto no aspecto material (normas de direitos humanos) quanto no aspecto processual (mecanismo de proteção). No tocante às normas de direitos humanos, cabe lembrar que podem ser utilizadas as normas previstas no Direito Internacional dos Direitos Humanos (v. g., a Convenção Americana de Direitos Humanos), uma vez que o Protocolo de Olivos dispõe, expressamente, que os árbitros mercosulinos podem aplicar os princípios de Direito Internacional sobre o tema. Quanto à parte processual protetora, é possível o uso do próprio sistema atual arbitral ad hoc do MERCOSUL, malgrado seus defeitos (em especial, aqueles relativos ao acesso dos particulares ao sistema). Tais soluções, apesar de imperfeitas como vimos, devem ser utilizadas, sob pena de ser o processo de integração alvo de ações perante o juiz brasileiro, que, ao invocar a cláusula pétrea de defesa de direitos humanos, pode impedir o fortalecimento do processo de integração. 
Com a entrada em vigor do Protocolo Constitutivo da Corte de Justiça do MERCOSUL - como parte integrante do Tratado de Assunção (art. 52) — estará derrogado o Protocolo de Olivos para a solução de controvérsias no bloco (art. 51), mas, como demonstrado, essa Corte — nos contornos apresentados no presente projeto — não se consolida como instância internacional e jurisdicional para a tutela, de modo amplo, dos direitos da pessoa humana, tendo-se que adotar outros mecanismos para esse controle.

Isto poderá enfraquecer o processo de integração regional no MERCOSUL, a consolidação de um Direito de Integração especificamente mercosulista, dificultando, por conseguinte, a formação de um Direito Comunitário no bloco e, ainda, poderá impedir a construção do tribunal jurisdicional supranacional permanente tão almejado pelo PARLASUL enquanto representante dos povos da região e de seus anseios.

\section{CONCLUSÃo}

Em face da existência de normas internacionais de proteção aos direitos humanos, de cunho global e regional, e das ordens constitucionais dos Estados democráticos as quais promoveram a valorização da dignidade da pessoa humana, mostra-se - como imperativo para a convivência pacífica entre os povos - a existência de controles jurisdicionais estatais do adimplemento e da correta aplicação dessas normas, sobretudo no âmbito dos processos de integração regional, sendo os tribunais supranacionais um caminho a ser adotado na resolução dos conflitos e na realização dos direitos humanos, além das medidas adotadas no campo político-diplomático.

O MERCOSUL se originou de diversas negociações entre o Brasil e a Argentina ocorridas durante a década de 1980, impulsionadas pela redemocratização dos países latino-americanos que encerrou um longo período de governos ditatoriais, sendo o Tratado de Assunção, assinado em 26 de março de 1991, o seu marco jurídico-institucional, sobretudo porque é um acordo de alcance parcial — o Acordo de Complementação Econômica (ACE) n. 18 - celebrado no âmbito da ALADI.

Então, em sua origem, o MERCOSUL assumiu mais uma feição de aliança comercial com vistas a dinamizar a economia regional com o desafio de sua conversão em mercado comum com livre circulação de bens, serviços, pessoas e capitais. Na circulação de pessoas, estão incluídos consumidores e trabalhadores que possuem direitos a serem protegidos por meio de normas comuns - um direito comum - entre os Estados-partes, o que ainda não há no MERCOSUL, e direitos a serem resguardados por um tribunal supranacional também inexistente no bloco.

Além disso, quando se pensa numa circulação ampla de bens, serviços, capitais e pessoas entre países diversos, necessariamente haverá ilícitos penais cometidos que também devem possuir regulação e tutela específicas também ausentes atualmente no bloco. Todas essas questões extrapolam o aspecto puramente comercial que envolve os países mercosulistas, sendo necessário se avançar mais na criação de instituições supranacionais.

As atividades dos seres humanos são exteriorizadas mediante relações entre os seus semelhantes ou de ações sobre os bens (materiais ou imateriais), estando todas reguladas 
pelo direito no âmbito das sociedades. No caso do MERCOSUL, não poderia ser diferente, mas os Estados-partes não se preocuparam com a tutela dos direitos (civis, políticos, sociais, trabalhistas etc.) da pessoa humana que devem também permear o processo de integração, pois eles não estavam previstos nos tratados que fundamentaram a criação e a institucionalização do bloco.

Porém, o MERCOSUL deve evoluir para se constituir num processo de integração regional mais amplo porque representa o acesso a uma identidade latino-americana, havendo a necessidade de desenvolvimento de regimes jurídico-políticos capazes de viabilizar a resolução de problemas comuns entre os Estados-partes e entre as pessoas (físicas e jurídicas), principalmente quando envolverem a tutela dos direitos humanos.

Os Estados-partes do MERCOSUL estão comprometidos com as declarações, os pactos e os tratados internacionais que integram o patrimônio ético-jurídico da humanidade, inclusive dos trabalhadores, destacando-se a Declaração Universal dos Direitos Humanos (1948), o Pacto Internacional dos Direitos Civis e Políticos (1966), o Pacto Internacional dos Direitos Econômicos, Sociais e Culturais (1966), a Declaração Americana de Direitos e Deveres do Homem (1948), a Convenção Americana sobre Direitos Humanos - Pacto São José da Costa Rica (1969), o Protocolo Adicional à Convenção Americana sobre Direitos Humanos em Matéria de Direitos Econômicos, Sociais e Culturais — Protocolo de São Salvador (1988), diversas Convenções e Declarações da Organização Internacional do Trabalho (OIT), dentre outros instrumentos normativos.

Nesse contexto, o Parlamento do MERCOSUL aprovou o Projeto de Norma da Corte de Justiça (MERCOSUR/PM/PN 02/2010) no intuito de implementar um tribunal jurisdicional permanente para consolidar a aplicação e interpretação uniforme das normas mercosulistas, dotando de maior segurança e certeza jurídicas o processo de integração. A necessidade de se elevar o nível institucional do bloco mediante a criação de instituições de caráter supranacional - como é o caso dessa Corte de Justiça - é primordial, sobretudo porque promove a consolidação do Estado Democrático de Direito e da tutela dos direitos das pessoas e dos povos mercosulistas. Essas justificativas foram também evidenciadas nos "FUNDAMENTOS" do projeto de norma:

[...] el enfrentamiento de la crisis no puede prescindir también de la construcción de órganos supranacionales en el ámbito del bloque, que provean de la imprescindible seguridad jurídica para todos los Estados Partes, entre los cuales destacamos un Tribunal de Justicia del MERCOSUR dotado de poderes para emitir sentencias vinculantes y de cumplimiento obligatorio. [...] es necesario encontrar el equilibrio entre la representación ciudadana con proporcionalidad atenuada y los imprescindibles avances hacia la creación de instituciones supranacionales, que profundicen el proceso de integración, que contribuy a a la superación de las asimetrías y que garantice a todos los Estados Partes y a sus ciudadanos la efectividad de los derechos que el proceso les confiere [...] en este sentido, resulta necesario, entre otros, la suscripción de un protocolo constitutivo de un Tribunal de Justicia del MERCOSUR, con facultades para atender cuestiones jurisdiccionales que sean sometidas a su consideración, cuyas resoluciones sean obligatorias en cada Estado Parte y que la institucionalidad es un tema clave para el futuro del proceso de integración, y en este debate no pueden estar ausentes el análisis, la discusión y las propuestas de los actores políticos y de la sociedad civil. (MERCOSUL, 2011d, p. 29) 
Porém, numa análise preliminar do projeto de norma proposto, ao se contemplar a competência em razão da matéria (ratione materiae) e os instrumentos jurídico-processuais desta futura Corte, entende-se que há certos limites e deficiências, sobretudo em relação à solução de conflitos que envolvam as matérias trabalhistas, penais e aos direitos da pessoa humana de um modo geral.

O projeto inova ao propor a criação de uma Corte Permanente de Justiça no MERCOSUL como órgão jurisdicional, dotando os juízes de total independência para o exercício de suas funções. Ele também se mostra inovador ao conceder às pessoas físicas e jurídicas, individualmente, uma capacidade processual e postulatória em nível internacional para interpor as ações de nulidade, as ações de descumprimento ou violação das obrigações emanadas do direito mercosulista, dentre outras, tornando-as legitimadas ativas para a propositura dessas demandas judiciais.

Entretanto, as pessoas ao terem seus direitos violados, principalmente no caso dos direitos humanos, serão obrigadas a optar entre a jurisdição da Corte de Justiça mercosulista e a jurisdição nacional de seus países porque são atuações jurisdicionais totalmente incompatíveis. Conforme constam nos "Fundamentos" do próprio projeto de norma, a jurisdição da Corte de Justiça é exclusiva e excludente.

Apesar dos avanços do projeto de norma ao conceder individualmente às pessoas a capacidade processual e postulatória internacional, elas têm que optar entre a jurisdição nacional de seu país e a jurisdição da Corte de Justiça, sendo opção excludente para a solução das controvérsias e restritiva do direito humano de acesso à Justiça o que é incompatível com o Estado Democrático de Direito e as normas internacionais, seja no plano global ou regional, de proteção aos direitos humanos.

Portanto, há um retrocesso nas garantias individuais dos cidadãos e da pessoa humana, afrontando os princípios da subsidiariedade e da complementaridade que norteiam a implantação de tribunais internacionais com caráter supranacional, como é o caso dessa proposta de Corte de Justiça para o MERCOSUL. Os Estados, as pessoas físicas, as pessoas jurídicas, enfim, todo o jurisdicionado que busca a atuação de tribunais internacionais não deve ficar impedido de esgotar a jurisdição nacional de seu próprio país no amparo de seus direitos para, talvez posteriormente, buscar a jurisdição internacional, pois essa sistemática torna ineficaz a tutela do tribunal supranacional, sobretudo ao se tratar de direitos humanos.

Além disso, a Corte de Justiça somente conhecerá as controvérsias de cunho meramente administrativo-laborais (relação jurídico-administrativa) que sejam suscitadas entre os órgãos do MERCOSUL e seus respectivos funcionários ou pessoas contratadas pelos mesmos para obras e serviços determinados.

A Corte - apesar de assumir a feição de órgão jurisdicional, judicial e independente - não resolverá os conflitos oriundos das relações de trabalho propriamente ditas que envolvam a prestação de trabalho humano, havendo um retrocesso na chamada "Jurisdição Laboral". Ante a ausência de competência dessa Corte em matéria trabalhista, restará aos trabalhadores do MERCOSUL apenas a reivindicação de seus direitos no local da prestação de serviços, consoante a legislação do respectivo Estado-parte, o que contribui para o enfraquecimento do processo de integração regional mercosulista. 
Outra restrição em matéria de competência da Corte de Justiça do MERCOSUL diz respeito aos conflitos no âmbito criminal envolvendo a apuração das responsabilidades dos autores dos fatos e a respectiva aplicação/execução das penas, principalmente em relação aos crimes de natureza transnacional (tráfico de pessoas; tráfico de entorpecentes, armas e órgãos; lavagem de capitais; aliciamento de trabalhadores etc.) que não serão apreciados nesta Corte, ficando enorme lacuna para o combate desses ilícitos penais que ultrapassam as fronteiras dos países.

Ademais, outro indício de "falha" neste Projeto de Corte de Justiça foi a proposta elaborada pela Ordem dos Advogados do Brasil - Seção de São Paulo - já entregue ao embaixador do Brasil no bloco Regis Arslanian em 19.03.2012 — para a criação do "Tribunal Penal do MERCOSUL" no intuito de suprir a ausência de competência para as lides penais. Apesar de ser importante e extremamente louvável essa proposta da OAB/ SP, acredita-se que a criação no âmbito do MERCOSUL de outro tribunal específico para tutelar os litígios criminais, poderá enfraquecer a criação de um tribunal supranacional no bloco. Seria mais adequado realizar uma emenda ao projeto de norma já aprovado no PARLASUL para a inclusão das lides penais na competência ratione materiae ao invés de se criar outro tribunal para o bloco.

Portanto, o projeto de norma para a instauração da Corte de Justiça do MERCOSUL cria uma jurisdição supranacional "incompleta" e competência material "limitada" porque não resolverá todas as espécies de litígios que poderão se constituir no bloco, principalmente quando envolverem as relações de trabalho e a apuração de crimes transnacionais, restringindo também o direito de acesso à Justiça. Logo, essa proposta de Corte não se consolida como instância jurisdicional internacional para o efetivo amparo aos direitos da pessoa humana.

Cabe ressaltar que a União Europeia possui um Tribunal de Justiça de caráter supranacional direcionado para o respeito e aplicação do Direito Comunitário e para a tutela dos direitos dos cidadãos do bloco. Portanto, esse Tribunal — diferentemente da proposta de Corte de Justiça do MERCOSUL — possui competência ampla para apreciar todas as espécies de litígios que impactam na vida dos cidadãos (pessoas físicas) e violem os seus direitos humanos. Ele também disciplina todas as relações sociais e jurídicas firmadas na UE sob o amparo do Direito Comunitário, não havendo restrição de sua atuação a questões meramente de cunho comercial. Isso demonstra que o Projeto de Norma de Corte de Justiça do MERCOSUL ainda tem que ser muito aperfeiçoado para atingir os objetivos propostos pelo PARLASUL.

Outrossim, há muitos questionamentos ainda em aberto que evolveriam a proposta de criação da Corte de Justiça do MERCOSUL e a tutela dos direitos da pessoa humana, tais como:

- Como ocorre a incorporação dos tratados de direitos humanos no ordenamento jurídico interno dos Estados-partes?

- Como o Direito Constitucional de cada país integrante do bloco trataria o tema dos direitos humanos? Seria compatível com a criação de um Direito Comunitário e de um Tribunal Supranacional? 
- As diferenças constitucionais no tratamento dos direitos humanos em cada Estado-parte impactariam na consolidação de uma Corte de Justiça de caráter supranacional?

- Seria possível realizar uma análise comparativa entre o MERCOSUL e outros blocos comerciais para verificar a possibilidade jurídica no estabelecimento de uma Corte de Justiça com competência ampla para a garantia dos direitos humanos?

- Seria viável que a Corte de Justiça fosse vinculada a alguma organização internacional como, por exemplo, a Organização dos Estados Americanos (OEA) ao invés de vinculada diretamente ao MERCOSUL?

Entretanto, a busca por essas respostas - dentre outras - ensejaria a realização de novas pesquisas, inclusive com maior aprofundamento da análise teórica, o que extrapola os objetivos e limites do presente artigo, mas isso não exclui a possibilidade de realização de futuras investigações.

Assim, para concluir, em função da dimensão internacional (e supranacional!) dos direitos da pessoa humana, não se deve permitir que o MERCOSUL "caminhe" para uma integração regional e mesmo para a constituição de uma "comunidade latino-americana de nações" sem que haja a criação de uma Corte Permanente de Justiça com competência jurisdicional ampla para a solução de controvérsias atinentes às diferentes áreas do Direito e da vida humana e não somente direcionada para questões de cunho comercial e administrativo como o presente projeto propõe. É necessário conceder aos povos mercosulistas, enquanto sujeitos de direito, a legitimidade ativa plena para processualmente reivindicar os seus direitos, havendo o monitoramento judicial dos descumprimentos e das violações dos mesmos pelo Tribunal supranacional mercosulista.

Essa proposta de uma Corte de Justiça para o MERCOSUL deveria alterar completamente a situação jurídico-institucional até então existente, permitindo a formação de um órgão jurisdicional e supranacional no bloco que garantisse a aplicação e a interpretação uniforme das normas nas relações entre os países mercosulistas, sobretudo se houvesse maior proteção aos direitos da pessoa humana na qualidade de consumidores, trabalhadores ou "cidadãos" do bloco (uma possível cidadania supranacional a ser construída).

Porém, apesar do PARLASUL propor - dentre outras metas - o estímulo à formação de uma consciência coletiva de valores comunitários para a integração mercosulista, não se sabe se a proposta de Corte de Justiça — nos contornos jurídico-institucionais ora analisados - poderá ser efetivamente viabilizada e implementada no MERCOSUL em face dos seguintes entraves: ausência de um Direito Comunitário no bloco, prevalência de um sistema intergovernamental de tomada de decisões centralizado nos Estados-partes e ausência de uma comunidade realmente estruturada no bloco. É necessária, ainda, a realização de novas pesquisas a esse respeito, o que será feito em momento oportuno.

\section{BiBLIOGRAFIA}

ARAÚJO, Francisco Rossal de. A natureza jurídica da relação de trabalho (novas competências da justiça do trabalho — emenda constitucional n. 45/04). In: COUTINHO, Grijalbo Fernandes eFAVA, Marcos Neve (coords.). Nova competência da justiça do trabalho. São Paulo: LTr, 2005. 
BARROSO, Luís Roberto. Neoconstitucionalismo e constitucionalização do direito. O triunfo tardio do direito constitucional no Brasil. Jus Navigandi, Teresina Ano 09, n. 851. Disponível em: <http:// jus2.uol.com.br/doutrina/texto.asp?id=7547> Acesso em: 07 nov. 2010.

BRAGA, Márcio Bobik. Integração econômica na América Latina: uma interpretação das contribuições da CEPAL. Cadernos PROLAM/USP, São Paulo: LTr Ano I, v. 1, n. 1, p. 01-26, 2002.

BRASIL.Código Penal Brasileiro. Disponível em:<http://www.planalto.gov.br/ccivil_03/decreto-lei/ del2848compilado.htm> Acesso em: 14 jun. 2012.

CEPAL. O regionalismo aberto na América Latina e no Caribe: a integração a serviço da transformação produtiva com equidade. In: Bielschowsky, Ricardo (org). Cinquenta anos de pensamento na CEPAL, COFECON/Record: Rio de Janeiro, 2000, p. 937-958.

DICIONÁRIO Houaiss Eletrônico de Língua Portuguesa. Disponível em:<http//:www.houaiss.uol. com.br> Acesso em: 18 jun. 2012.

FERRAJOLI, Luigi. A soberania no mundo moderno. São Paulo: Martins Fontes, 2002.

FURLAN, Fernando de Magalhães. Supranacionalidade nas associações de Estados: repensando a soberania. Curitiba: Juruá, 2008.

GAMBA, Juliane Caravieri Martins. A concretização do trabalho digno no MERCOSUL: dilemas da integração regional. Cadernos PROLAM/USP, São Paulo: LTr Ano IX, v. 2, n. 17, p. 136-157, 2010.

O MERCOSUL e a construção do tribunal supranacional trabalhista: em busca da realização do direito humano ao trabalho digno. Revista do Ministério Público do Trabalho, São Paulo: LTr, v. 42, p. 290-318, 2011.

GARCIA, Maria. A integração dos Estados. O Brasil no MERCOSUL: implicações e abrangência na ordem interna e internacional. Revista de Direito Constitucional e Internacional, São Paulo: Revista dos Tribunais A. 9, n. 35, p. 16-23, 2001.

JORNAL O ESTADÃO. Anteprojeto de norma para criação do tribunal penal do MERCOSUL. Disponível em: <http://www.estadao.com.br/especiais/2012/02/proposta-final-tribunal-penal-mercosul. pdf> Acesso em: 23 jul. 2012.

JUSCLIP. OAB SP entregará proposta para criação do tribunal penal internacional do MERCOSUL. Disponível em: <http://jusclip.com.br/oab-sp-entregara-proposta-para-criacao-do-tribunal-penal-internacional-do-mercosul/> Acesso em: 23 fev. 2012.

LEITE, Carlos Henrique Bezerra. Curso de direito processual do trabalho. 5. ed. São Paulo: LTr, 2007. LOBO, Maria Teresa de Cárcomo. Manual de direito comunitário. Curitiba: Juruá, 2007.

LUÑO Antonio Enrique Perez. Los derechos fundamentales. 9. ed. Madrid: Tecnos, 2007.

MERCOSUL. Comissão Parlamentar Conjunta do Mercosul. Disponível em: <http://www.camara.gov. br/mercosul.htm> Acesso em: 23 ago. 2011(a).

Declaração sociolaboral do mercosul. Edição Comemorativa. Disponível em: <http:// www.mte.gov.br/eventos/mercosul/decl_pt.pdf> Acesso em: 07 nov. 2011(b).

Proyecto de Norma - Corte de Justicia del Mercosur (MERCOSUR/PM/PN 02/2010). Disponível em: <http://www.parlamentodelmercosur.org/innovaportal/file/5130/1/Proyecto\%20 de\%20norma\%20Corte\%20de\%20Justicia.pdf> Acesso em: 08 jul. 2011(c).

. Protocolo Constitutivo do Parlamento do MERCOSUL. Disponível em: <http://www.mercosul.gov.br/tratados-e-protocolos/protocolo-constitutivo-do-parlamento-do-mercosul/> Acesso em: 08 jul. 2011(d).

. Protocolo de Olivos. Disponível em: <http://www.mercosul.gov.br/tratados-e-protocolos/ protocolo-de-olivos-1/> Acesso em: 08 jul. 2011(e). 
Protocolo de Ouro Preto. Disponível em: <http://www.mercosul.gov.br/tratados-e-protocolos/protocolo-de-ouro-preto-1/> Acesso em: 08 jul. 2011(f).

MONTAL, Zélia Maria Cardoso. Convenções da OIT: incorporação e impacto na ordem jurídica interna e a responsabilidade internacional do Estado. Dissertação (Mestrado em Direito), Pontifícia Universidade Católica de São Paulo, São Paulo, 2009, 259p.

OAB. Seccional entrega proposta de criação do tribunal penal do MERCOSUL. Disponível em: <http:// www.oabsp.org.br/noticias/2012/03/29/7809/> Acesso em: 23 maio 2012.

PIOVESAN, Flávia. Globalização econômica, integração regional e direitos humanos. In: PIOVESAN, Flávia. (Coord.). Direitos humanos, globalização econômica e integração regional. São Paulo: Max Limonad, 2003. p. 39-75.

RAMOS André de Carvalho. Direitos humanos na integração econômica: análise comparativa da proteção de direitos humanos e conflitos jurisdicionais na União Europeia e MERCOSUL, Rio de Janeiro: Renovar, 2008.

RÁO, Vicente. O direito e a vida dos direitos. 6.ed. São Paulo: Revista dos Tribunais, 2005.

ROSA, Elianne Maria Meira. Constitucionalismo social no MERCOSUL. São Paulo: Themis Livraria e Editora, 2002.

SARLET, Ingo Wolfgang. A eficácia dos direitos fundamentais. Porto Alegre: Livraria do Advogado, 2008.

SILVA, José Afonso. Direito regional, direitos humanos e direito comunitário. In: PIOVESAN, Flávia (coord.). Direitos humanos, globalização econômica e integração regional. São Paulo: Max Limonad, 2003. p. 17-38.

UNASUL. Tratado Constitutivo da União de Nações Sul-Americanas. Disponível em: <http://www. itamaraty.gov.br/temas/america-do-sul-e-integracao-regional/unasul> Acesso em: 23 maio 2011.

UNIÃO EUROPEIA. Tribunal de Justiça da União Europeia. Disponível em: < http://curia.europa.eu> Acesso em: 22 jul. 2012.

WAMBIER, Luiz Rodrigues (Coord.). Curso avançado de processo civil. v. 1, 3. ed. rev. atual. e ampl., São Paulo: Revista dos Tribunais, 2000. 